\title{
Kullanıma hazır dondurulmuş gölevez üretimi
}

\section{Ready-to-use frozen taro production}

\author{
Manolya Eser ÖNER ${ }^{1 *}$, Erman BAŞ ${ }^{2}$, Mehmet Durdu ÖNER ${ }^{2}$ iD
}

${ }^{1}$ Alanya Alaaddin Keykubat Üniversitesi, Mühendislik Fakültesi, Gıda Mühendisliği Bölümü, Alanya, Antalya

${ }^{2}$ Alanya Hamdullah Emin Paşa Üniversitesi, Sanat ve Tasarım Fakültesi, Gastronomi ve Mutfak Sanatları Bölümü, Alanya, Antalya

\section{To cite this article:}

Öner, M.E, Baş, E. \& Öner, M.D. (2020). Kullanıma hazır dondurulmuş gölevez üretimi. Harran Tarım ve Gıda Bilimleri Dergisi, 24(2): 174-184.

DOI: 10.29050/harranziraat.634265

Address for Correspondence: Manolya Eser ÖNER

E-mail:

manolya.oner@alanya.edu.tr

Received Date:

17.10.2019

Accepted Date:

29.01.2020
Öz

Gölevez (Colocasia esculenta (L.) Schott) Akdeniz sahillerinde çok fazla yetiştirilen, patatesten çok daha fazla lif, potasyum, magnezyum ve çinko içeren bir tarım ürünüdür. Mineral miktarı yörede çok üretilen ve tüketilen muzdan yüksek olup, glisemik indeksi patatesten çok düşüktür. Gölevez yumrularının patatesten daha sert olan yapısı, soyulduğu ve kesildiği zaman çok fazla müsilaj çıkışı olması, ayrıca hasat sonrası raf ömrünün kısa olması nedeniyle tüketimi azdır. Bu çalışmanın amacı yüksek kaliteli ve besinsel değerlerinin korunduğu kullanıma hazır dondurulmuş kızartmalık gölevez üreterek tüketimini artırmaktır. Bunun için uygulanan işlemler asitli çözeltilerde bekletme, $85 \pm 1^{\circ} \mathrm{C}^{\prime}$ de 2,4 ve $6 \mathrm{dk}$ haşlama, $20 \pm 1^{\circ} \mathrm{C}^{\prime}$ de 5 dk soğutma, $180 \pm 1^{\circ} \mathrm{C}^{\prime}$ de $1 \mathrm{dk}$ ön kızartma ve $-18 \pm 1^{\circ} \mathrm{C}^{\prime}$ de 6 ay depolamadan oluşmaktadır. İşlemlerden geçirilen ve depolanan gölevez ürünlerine küf, nem, kül, su tutma kapasitesi, yağ tutma kapasitesi, renk ve duyusal analizler yapılmıştır. Küf analizi sonuçlarına göre $85 \pm 1^{\circ} \mathrm{C}^{\prime} \mathrm{de}$ $6 \mathrm{dk}$ haşlama işleminin ürünün $-18 \pm 1^{\circ} \mathrm{C}^{\prime}$ de 6 ay saklanabilmesi için gerekli olduğu belirlenmiştir. Ürünlerin su tutma kapasitesi arttıkça yağ tutma kapasitesinde azalma olmuştur. Limonlu çözeltide bekletilip, haşlama işleminin ardından ön kızartma uygulanan ürünlerde kül oranı diğer ürünlerden daha yüksek çıkmıştır. Ön kızartma işlemi uygulandığı zaman $L^{*}$ değerinde artış, $a^{*}$ ve $b^{*}$ değerlerinde düşme dolayısıyla renkte koyulaşma ve sarımsı renkte azalma gözlemlenmiştir. Duyusal analiz sıralama testi sonucunda en çok tercih edilen sitrik asit çözeltisinde bekletilip ön kızartma uygulanan (Lt6-K), en az tercih edilen ise sirkeli suda bekletilip ön kızartma uygulanan (S6-K) ürün olmuştur.

Anahtar Kelimeler: Gölevez, Dondurulmuşürün, Duyusal analiz, Renk

\section{ABSTRACT}

Taro (Colocasia esculenta (L.) Schott) is widely grown agricultural product in Mediterranean region. When compared to potato, it contains higher amount of fiber, potassium, magnesium, and zinc. Mineral content of taro is higher than banana, which is the most produced and consumed product in this area. In addition, glycemic index of taro is lower compared to white potato. Taro consumption is low because of hard texture, high amount of mucilage comes off during peeling and cutting, and short postharvest shelf-life. The objective of this project is to increase the consumption of taro by producing high quality, ready-to-use, and nutritious frozen taro fries. Treatments consist of dipping into acidic solutions, blanching at $85 \pm 1^{\circ} \mathrm{C}$ for $2,4,6 \mathrm{~min}$, cooling at $20 \pm 1^{\circ} \mathrm{C}$ for $5 \mathrm{~min}$, par-frying at $180 \pm 1^{\circ} \mathrm{C}$ for $1 \mathrm{~min}$, and storing at $-18 \pm 1^{\circ} \mathrm{C}$ for 6 months. Treated products were analyzed for mold count, moisture content, ash content, water retention and oil holding capacities, color and sensorial quality. Based on mold count, blanching at $85 \pm 1^{\circ} \mathrm{C}$ for 6 min was required to be able to store product at $-18 \pm 1^{\circ} \mathrm{C}$ for 6 months. When water retention capacity of the product decreased, oil holding capacity increased. Higher ash content was determined in taro products treated with lemon solution, blanched and then par-fried compared to other products. Par-frying increased $\mathrm{L}^{*}$, decreased $\mathrm{a}^{*}$ and $\mathrm{b}^{*}$ values, thereby increase in darkness and decrease in yellowness was observed in taro products. According to the sensory analysis ranking test, par-fried taro treated with citric acid (Lt6-K) was the most, whereas taro treated with vinegar (S6-K) was the least preferred one. 


\section{Giriş}

Nişastalı bitkiler sınıfından olan Gölevezin [Colocasia esculenta (L.) Schott], tropik ülkelerde yaygın adı "Taro" olarak kullanılsa da ülkelere göre "kolokas, old cocoyam, eddoe veya dasheen" adını alır (Göhl, 1981). Gölevez, sıcaklığın $0^{\circ} \mathrm{C}$ derecenin altına düşmediği, sulama olanakları uygun, rutubetli arazilerde ve ırmak yataklarında yetişir (Şen ve ark., 2001). Akdeniz bölgesinde İçel ilinin Anamur ve Bozyazı ilçeleri ile Antalya ilinin Alanya ve Gazipaşa ilçelerinin sahil kesimlerinde patatesten daha çok yetiştirilir ve tüketilir (Akgül ve ark., 2017). Her yıl ürün veren bu bitkinin yumruları küre veya silindir şeklinde olup, yaprakları fil kulağına benzemektedir. Yumruların dış kabuğu kahverengi, iç kısmı ise beyaz renklidir. Gölevez nişasta, magnezyum ve potasyum bakımından zengin bir bitkidir (Şen ve ark., 2001). İçeriğinde $0.6-0.8 \mathrm{~g} / 100 \mathrm{~g}$ lif ve 2-6 g /100 g protein vardır (Sefa-Dedeh ve Agyir-Sackey, 2004). Gölevezdeki nişasta miktarı \%15 ile \%25 arasında değişmektedir. Protein ve yağ değeri düşük olup, karbonhidrat, lif ve mineral (Ca, K, Na ve P) bakımından zengindir. Gölevezin mineral değeri çok tüketilmekte olan muzdan yüksektir (USDA, 2017). Ancak bu oranlar gölevezin türüne, yetişme şartlarına, yetiştiği toprak türüne, neme, olgunlaşmasına ve hasat edildikten sonraki saklama koşullarına göre değişiklik gösterebilir (Arnaud-Vinas ve Klaus, 1999).

Yumrular genellikle un ve/veya nişasta üretiminde kullanılmaktadır. Gölevez unu içeriğindeki küçük granüllü kolay sindirilebilir nişasta sebebiyle bebek mamalarında kullanılmaktadır (Palaniswami ve Peter, 2008). Türkiye'de yetiştirilen gölevezden püre ve kızartma üretimi ile ilgili araştırma yapılmış, duyusal analizlerde püreye göre kızartma daha çok beğenilmiştir (Şen ve ark., 2001). Ancak gölevez yumrularının hasat sonrası raf ömrü, yüksek nem oranı, mekanik hasarlar, fiziksel bozulmalar (solunum, filizlenme vb.) ve mikrobiyal bozulmalardan dolayı kısadır (Agbor-Ekbe ve Rickard, 1991). Aktif halde bulunan peroksidaz ve polifenol oksidaz enzimleri nedeniyle enzimatik kahverengileşmeye elverişlidir (Yemenicioğlu ve ark., 1999). Bunun yanında gölevez yumruları patatesten daha sert yapıdadır. Kesildiği zamanda yapışkan özellikte müsilaj çıkışı olmaktadır. Saklama ve hazırlama aşamasındaki zorluklar gölevez tüketimini azaltmaktadır.

Dondurma işlemi meyve ve sebzelerin kimyasal, biyokimyasal ve mikrobiyolojik değişimlerini durdurmak ya da en aza indirmek, böylece raf ömrünü uzatmak için uygulanır (Demiray ve Tülek, 2010). Dondurularak saklanan gıdalarda tat, koku gibi kalite kriterleri ve besin değerlerinde değişme az ya da hiç olmadığı gözlemlenmiştir (Sarıkaya ve Korkmaz, 2012). Dondurulmuş gıda tüketiminde sosyo-ekonomik ve davranışsal değişkenlerin etkisi büyüktür (Gündüz ve Emir, 2014). Türkiye'de dondurulmuş meyve ve sebze tüketimi İstanbul, İzmir, Ankara ve Bursa gibi büyük kentler ve batı bölgelerindedir (ITO, 2003). Ancak ülkemizin zengin doğal kaynakları, batısından doğusuna coğrafi konumu, artan şehirleşmeler ve nüfusun yanı sıra büyüyen ve gelişen ekonomi ile dondurulmuş gıda sanayinin gelecekte artış göstermesi beklenmektedir (Külekçi ve ark., 2006). Bütün dünyada en fazla tüketilen dondurulmuş ürün patatestir (ITO, 2003). Patates kızartması daha çok hazır yiyeceklerin (fast-food) yanında tüketilmektedir. Dondurulmuş kızartmalık patates farklı boyutlarda (parmak, elma dilimi vs.) tüketiciye sunulmaktadır. Ancak tüketilen beyaz patates türü $(144 \pm 22)$ glisemik indeks bakımından beyaz ekmekten (100) çok daha yüksektir (FosterPowell ve ark., 2002). Bu sebeple, ABD gibi hazır yiyeceklerin çok tüketildiği ülkelerde kızartılmış beyaz patates yerine tatlı patates gibi glisemik

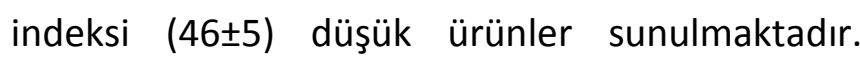
Gölevez glisemik indeks bakımından orta seviyededir (Simsek ve El, 2015). Yapılan bir çalışmada, gölevezin glisemik indeksinin (72 \pm 5$)$ tatlı patatese $(46 \pm 5)$ oranla yüksek (Bahado-Singh ve ark., 2006) ancak başka bir çalışmada beyaz

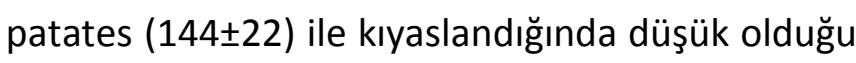
ortaya çıkmıştır (Foster-Powell ve ark., 2002). Mineraller ( $\mathrm{Ca}, \mathrm{Na}, \mathrm{K}$ ve $\mathrm{Cl}$ ) bakımından oldukça zengin, beyaz patates türüne göre düşük olan glisemik indeksi ile gölevezden üretilecek olan 
dondurulmuş kızartmalık ürün, sağlıklı gıda tüketmek isteyenler için alternatif olarak sunulabilir. Bu çalışmada, yumrular dilimleme, asidik çözeltide bekletme, haşlama, ön kızartma, dondurma ve paketleme işlemlerinden geçirilerek, kullanılmaya hazır, yüksek kalitede ve besinsel değerlerinin korunduğu, raf ömrü uzun, dondurulmuş gölevez üretimi amaçlanmıştır.

\section{Materyal ve Metot}

\section{Gölevezin hazırlanması ve işlenmesi}

Araştırmada kullanılan gölevez yumruları (Colocasia esculenta (L.) Schott) yerel bir üreticiden (Alanya, Antalya, Türkiye) hasat edildikten sonra bir gün içerisinde temin edilmiş ve araştırmada kullanılmıştır. Yumruların dış kabukları soyulduktan sonra $1 \times 1 \times 5 \mathrm{~cm}$ standart ölçüde, sanayi tipi patates dilimleme makinesi (Özlem Mühendislik ve Madeni Eşya A.Ş., Türkiye) ile dilimlenmiştir (Oner ve Wall, 2012). Çizelge 1'de gösterildiği gibi dilimlenen ürünler, yüzey oksidasyonunu azaltmak ve yüzeydeki müsilaj oranını düşürmek amacıyla, üzüm sirkeli (\%5 (v/v); pH: 3.00) (Tariş, Türkiye), sitrik asitli (\%0.5 (w/v); $\mathrm{pH}: 3.00)$ (Arifoğlu, Türkiye) ve limonlu (\%5 (v/v); $\mathrm{pH}: 3.00)$ çözeltilerde yaklaşık olarak 2 saat bekletilmiştir. Hazırlanan ürünlere $85 \pm 1^{\circ} \mathrm{C}^{\prime}$ de 2,4 ve 6 dakika haşlama işlemi uygulanmış $(1.5 \mathrm{~kg}$ ürün/4L su), sonrasında soğuk suda bekletme yapılarak ürünlerin oda sıcaklığına ulaşması sağlanmıştır. Sadece ön haşlama uygulanacak ürünler, kağıt havlu ile nemi alındıktan sonra kilitli poşete (Cook kilitli buzdolabı poşeti, Sedat Tahir A.Ş., Türkiye) paketlenip, $-18 \pm 1^{\circ} \mathrm{C}$ dondurucuda 6 ay depolanmıştır. Ön kızartma işlemi uygulanan ürünler ise haşlama işleminden sonra frita yağında (Orkide bitkisel susuz yağ, Küçükbay Yağ ve Deterjan Sanayi A.Ş., Türkiye) $180 \pm 1^{\circ} \mathrm{C}^{\prime}$ de sıcaklık kontrollü fritözde (Sinbo Deep Fryer, SDF-3827, Türkiye) 1 dakika kızartma işleminden geçirilmiş, yağı süzülen ürünler kilitli poşetlerde $-18 \pm 1^{\circ} \mathrm{C}^{\prime}$ de 6 ay süre ile saklanmıştır (Oner ve Wall, 2012).

\section{Son kızartma işlemi}

Kullanıma hazır dondurulmuş gölevez ürünlerine (1.5 kg) $180 \pm 1^{\circ} \mathrm{C}^{\prime}$ de frita yağında (3L) sıcaklık kontrollü fritöz kullanılarak 5, 7 ve 9 dakika son kızartma işlemi uygulanmıştır (Oner ve Wall, 2012).

\section{Küf analizi}

Altı ay süre ile $-18 \pm 1^{\circ} \mathrm{C}^{\prime}$ de saklanan 18 kullanıma hazır gölevez ürününe ve işlemsiz ürüne (Çizelge 1) küf analizi Alanya Çevre Laboratuvarı Müh. Tic. Ltd. Şti. (Türkiye) tarafından yapılmıştır. Bu analizde 25 g örnek $225 \mathrm{~mL}$ Maximum Recovery Diluent ile homojenize edilmiştir. Başlangıç dilüsyonundan $0.1 \mathrm{~mL}$ alınarak Dichloran Rose Bengal Chloramphenicol agar (DRBC, Merck, Almanya) içeren petriye aktarılmış, steril bir drigalski spatülüyle besiyeri yüzeyine yayılmış ve $25 \pm 1^{\circ} \mathrm{C}^{\prime}$ de 5 gün süreyle inkübasyona bırakılmıştır. İnkübasyondan sonra <150 koloni içeren petriler sayılmıştır. Küf analizi 2 paralel şeklinde yapılmıştır.

\section{pH tayini}

$\mathrm{pH}$ metre (Seven Excellence, Mettler Toledo, Çin) ile bekletme çözeltilerinin ve dondurma işleminden önce işlenmiş gölevez ürünlerinin $\mathrm{pH}$ değerleri ölçülmüştür. Bir gram işlenmiş gölevez ürünü $10 \mathrm{~mL}$ saf su ile stomacherde (Bagmixer ${ }^{\circledR}$ 400, CC, Fransa) işlemden geçirilmiş ve daha sonra pH değeri belirlenmiştir (Uylaşer ve Başoğlu, 2014).

\section{Nem tayini}

Nem tayini ön kızartma işleminden önce ve sonra yapılmıştır (AOAC, 1997). Darası alınan petrilere $1 \mathrm{~g}$ örnek tartılmış, ağırlık sabitleşinceye kadar $105^{\circ} \mathrm{C}$ etüvde (Memmert UF 110 , Almanya) bekletilmiştir. Daha sonra petri ve kuru numunenin ağırlığı ölçülmüş, nem oranı \% (g/g) kuru bazda hesaplanmıştır. 
Çizelge 1. Kullanıma hazır dondurulmuş gölevez ürünlerine uygulanan işlemler Table 1. Treatments for ready-to-use frozen taro products

\begin{tabular}{|c|c|c|c|}
\hline $\begin{array}{l}\text { Ürün Kodu² } \\
\text { Sample Code }\end{array}$ & $\begin{array}{l}\text { Bekletme Çözeltileri } \\
\text { Holding Solution }\end{array}$ & $\begin{array}{l}\text { Ön Kızartma İşlemi }\left(180 \pm 1^{\circ} \mathrm{C}, 1 \mathrm{dk}\right) \\
\text { Par-frying Process }\left(180 \pm 1^{\circ} \mathrm{C}, 1 \mathrm{dk}\right)\end{array}$ & $\begin{array}{l}\text { Haşlama Süresi (dk) }\left(85 \pm 1^{\circ} \mathrm{C}\right) \\
\text { Blanching Time (min) }\left(85 \pm 1^{\circ} \mathrm{C}\right)\end{array}$ \\
\hline $\begin{array}{l}\text { İşlemsiz Ürün }{ }^{1} \\
\text { Control }^{1}\end{array}$ & - & - & - \\
\hline $\mathrm{S} 2-\mathrm{H}$ & & - & 2 \\
\hline S2-K & & + & 2 \\
\hline S4-H & Sirkeli Çözelti & - & 4 \\
\hline S4-K & Vinegar Solution & + & 4 \\
\hline S6-H & & - & 6 \\
\hline S6-K & & + & 6 \\
\hline $\mathrm{Li} 2-\mathrm{H}$ & & - & 2 \\
\hline Li2-K & & + & 2 \\
\hline $\mathrm{Li} 4-\mathrm{H}$ & Limonlu Çözelti & - & 4 \\
\hline Li4-K & Lemon Solution & + & 4 \\
\hline Li6-H & & - & 6 \\
\hline Li6-K & & + & 6 \\
\hline $\mathrm{Lt} 2-\mathrm{H}$ & & - & 2 \\
\hline Lt2-K & & + & 2 \\
\hline $\mathrm{Lt} 4-\mathrm{H}$ & Limon tuzlu Çözelti & - & 4 \\
\hline Lt4-K & Citric acid Solution & + & 4 \\
\hline Lt6-H & & - & 6 \\
\hline Lt6-K & & + & 6 \\
\hline
\end{tabular}

\footnotetext{
${ }^{1}$ Hiçbir işlem uygulanmamış, kontrol
}

${ }^{2}$ S: Sirkeli çözelti; Li: Limonlu çözelti; Lt: Sitrik asitli çözelti; H: Haşlama (Sadece haşlama işlemi uygulandığını); K: Ön kızartma (Haşlama işlemi sonrasında kızartma işlemi uygulandığını); rakam haşlama süresini göstermektedir.

${ }^{1}$ Sample with no treatment, control

${ }^{2}$ S: Vinegar solution; Li: Lemon solution; Lt: Citric acid solution; H: Blanching (application of only blanching); K: Par-frying (application of frying after blanching treatment); number indicates blanching time.

\section{Kül tayini}

Kül tayini son kızartma işleminden önce ve sonra uygulanmıştır (AOAC, 2005). Kurutulmuş ürünler, daraları alınmış krozelerin içerisine yerleştirilip, kül fırınında (Protherm Furnaces PLF $110 / 15$, Türkiye) 6 saat $550^{\circ} \mathrm{C}^{\prime}$ de yakılarak bekletilmiştir. Daha sonra desikatörde, oda sıcaklığına kadar soğutulup, tartımı yapılıp, kül oranı \% (g/g) kuru bazda hesaplanmıştır.

\section{Su tutma kapasitesi}

Su tutma kapasitesi (STK) belirlemek için son kızartma işlemi öncesi ve sonrasında gölevez örnekleri blender (Fakir Hausgeräte, Almanya) ile toz haline getirilmiştir. İki gram örnek ile $10 \mathrm{~mL}$ distile su santrifüj tüpünün içine yerleştirilmiş ve 20 dakika 3000 RFC'de santrifüj (SIGMA, D-37520 Osterde am Harz, Almanya) edilmiştir (Hayta ve ark., 2002). Süpernatant uzaklaştırılmış, sediment ağırlığı tartılmıştır. STK \% (g/g) kuru bazda hesaplanmıştır.

\section{Yağ tutma kapasitesi}

Yağ tutma kapasitesini (YTK) belirlemek için son kızartma işlemi öncesi ve sonrasında gölevez örnekleri blender (Fakir Hausgeräte AC220-24V$50 / \mathrm{Hz} 500 \mathrm{~W}$ ) ile toz haline getirilmiştir. Iki g toz örneğe $10 \mathrm{~mL}$ sıvı yağ eklenerek santrifüj tüplerinin içine yerleştirilmiş ve ardından 20 dakika 3000 RFC'de santrifüj (SIGMA, D-37520 Osterde am Harz, Almanya) edilmiştir. Süpernatant uzaklaştırımış, sediment ağırlığı tartılmıştır. YTK \% (g/g) kuru bazda hesaplanmıştır (Bilgiçli, 2009).

\section{Renk tayini}

$1 \times 1 \times 5 \mathrm{~cm}$ halinde hazırlanmış olan yarı mamül gölevez örnekleri yan yana dizilerek, farklı noktalardan renk tayini cihazı (Konica Minolta Chroma Meter CR-5, Konica Minolta Optics Inc., Japonya) ile ölçüm yapılmış, L* (açıklık-koyuluk), a* (yeşillik-kırmızılık), b* (sarılık-mavilik) ve $\Delta \mathrm{E}^{*}$ (toplam renk farkı) değerleri belirlenmiştir (Oner ve Walker, 2011). Renk tayini, örneklere son kızartma işleminden önce ve sonra uygulanmıştır. 


\section{Duyusal analiz}

Duyusal analiz puanlama testi ile ürünlerin renk, gevreklik, sertlik, tat, koku, yağlılık oranı, ağızda kalan tadı beğenme derecesi, yabancı tat ve genel beğenisini 5 (çok iyi) - 4 (iyi) - 3 (normal) - 2 (kötü) - 1 (çok kötü) olarak değerlendirilmiştir (Altuğ Onoğur ve Elmacl, 2015). Sıralama testinde ise en çok beğenilen üründen en az beğenilene doğru ürünler arasında sıralama yapılmıştır.

Duyusal analize panelist olarak Alanya Hamdullah Emin Paşa Üniversitesi (Antalya, Türkiye) lisans ve yüksek lisans öğrencileri, akademik ve idari personelinden oluşan 31 kişi katılmıştır. Panelistlere duyusal analiz öncesinde sıcak servisin önemi anlatılmış ve üründe aranan özellikler ile ilgili bilgilendirme yapılmıştır (Oner ve Wall, 2012). Donmuş yarı mamül 7 farklı gölevez ürünleri frita yağında sıcaklık kontrollü fritöz kullanılarak $180 \pm 1^{\circ} C^{\prime}$ de 7 dakika kızartılmıştır. Kızartma sonrasında 3 dakika içerisinde kapalı beyaz plastik kaplar içerisinde panelistlere sunulmuştur.

\section{Istatistiksel analiz}

Dondurulmuş kullanıma hazır gölevez ürünü analiz sonuçları ortalama \pm standart sapma olarak gösterilmiştir. Analizler 3 paralel olarak uygulanmıştır. SPSS (Statistics 22.0, New York, USA) paket programı ile tek yönlü varyans analizi (ANOVA) yapılmıştır (Oner ve Walker, 2011). Ürünler arasındaki farklılığı belirlemek için Duncan çoklu sıralama testi (Duncan's Multiple Range Test) uygulanmıştır.

\section{Bulgular ve Tartışma}

Gıdaların hasat edilmesi, işlenmesi, taşınması ve depolanması esnasında yetersiz önlemler alınması sonucu gıdalarda çeşitli küf ve mayalar oluşur ve bozulmalar meydana gelir. Bu sebepten küf analizi gıdaların raf ömrünün belirlenmesinde önemli faktörlerden biridir (Kaya ve Demirel Zorba, 2018). Ayrıca, küfün vücudumuzda çeşitli organlarda birikmesi gibi sağlığa olumsuz etkileri olduğu bilinmektedir. Bu çalışmada, gölevez dilimleri sirkeli, limonlu ve sitrik asitli çözeltilerde 2 saat bekletilip 2, 4 ve 6 dakika $85 \pm 1^{\circ} \mathrm{C}^{\prime}$ de haşlama işlemi ya da haşlama işlemi ve sonrasında $180 \pm 1^{\circ} \mathrm{C}$ ' de 1 dakika ön kızartma uygulanarak, 18 kullanıma hazır gölevez örneği elde edilmiş, $-18 \pm 1^{\circ} \mathrm{C}^{\prime}$ de 6 ay süre ile saklanmıştır. Saklama süresi sonrasında uygulanan küf analizi sonuçlarına göre haşlama işlemi $85 \pm 1^{\circ} \mathrm{C}^{\prime}$ de 2 veya 4 dakika uygulanan ürünlerde küf belirlenmiştir. Bu sebeple 6 dakika haşlama işlemi uygulanan 6 kullanıma hazır dondurulmuş gölevez örneği (S6-H, S6-K, Li6-H, Li6$\mathrm{K}$, Lt6-H, Lt6-K) ile çalışmaya devam edilmiştir.

$\mathrm{pH}$ değerlerine bakıldığında, işlemsiz gölevez ürününün pH'sı 6.7 olarak belirlenirken, asitli çözeltilerde $(\mathrm{pH}: 3)$ bekletilen kullanıma hazır dondurulmuş ürünlerin $\mathrm{pH}^{\prime} \operatorname{sının} 6.2$ ile 6.4 arasında değiştiği gözlemlenmiştir. İstatistiksel olarak işlemsiz ürün ile işlemden geçirilmiş ürünler arasındaki farkın anlamlı olduğu $(p<0.05)$, bekletme çözeltilerinin kullanıma hazır dondurulmuş gölevez ürünlerinin asitlik oranını yükselttiği belirlenmiştir. Bunun yanı sıra Çizelge 2'de gösterildiği gibi, işlemsiz ürün ile sadece haşlama işlemi uygulanmış dondurulmuş ürünlerin (S6-H; Li6-H; Lt6-H) nem oranları arasında istatistiksel farkın anlamlı olmadığı ( $p>0.05)$ ancak haşlama işlemi sonrasında 1 dakika ön kızartma uygulanan ürünlerin (S6-K; Li6-K; Lt6-K) nem oranında düşüş gözlemlenmiştir $(p<0.05)$. Kızartma süresi arttıkça uzun süre ısı teması olan üründe, su buharlaşmasıyla nem oranının düştüğü belirlenmiştir (Açar, 2011). Ayrıca işlem sırasında sirkeli, limonlu ya da sitrik asitli çözeltide 2 saat bekletilmesi, kullanıma hazır dondurulmuş ürünlerin nem oranına etkisi olmamıştır. Çizelge 3'te gösterildiği gibi benzer nem oranı sonuçları $180 \pm 1^{\circ} \mathrm{C}^{\prime}$ de 5,7 ve 9 dakika son kızartma işleminden sonrada ortaya çıkmıştır.

Sirkeli, limonlu ya da sitrik asitli çözeltilerde bekletilen $85 \pm 1^{\circ} \mathrm{C}^{\prime}$ de 6 dakika sadece haşlama işlemi (S6-H; Li6-H; Lt6-H) ya da haşlama işlemi sonrasında $180 \pm 1^{\circ} \mathrm{C}^{\prime}$ de 1 dakika ön kızartma işlemi (S6-K; Li6-K; Lt6-K) uygulanan ürünlerin kül oranları arasında istatistiksel olarak fark bulunmamıştır (Çizelge 2). Ancak yapılan bir çalışmada, kızartıımış gölevez ürünlerinde kül oranının yükseldiği belirlenmiştir (Ahromrit ve Nema, 2010). Benzer 
sonuçlara limonlu çözeltide bekletilen ürünlerde rastlanmıştır (Çizelge 3). Son kızartma işlemi $\left(180 \pm 1^{\circ} \mathrm{C}^{\prime}\right.$ de 5,7 ve 9 dakika) uygulanan ürünlerden, limonlu çözeltide bekletilip, haşlama işleminin ardından ön kızartma uygulananlarda kül oranı yüksek çıkmıştır $(p<0.05)$. Ancak sirkeli ve sitrik asitli çözeltide bekletilen ürünlerin kül oranlarındaki farklılıklarının, bekletme çözeltilerinin ürün yapısına etkisi ile minerallerin çözeltide bekletme süresinde ya da kızartma sırasında yağa geçmesinden kaynaklandığı düşünülmektedir.

Kullanıma hazır dondurulmuş gölevez ürünlerinin su tutma kapasitesinde, haşlama işlemi sonrasında ön kızartma uygulanan ürünler ile sadece haşlama işlemi uygulanan ürünler kıyaslandığında, artış gözlemlenmiştir (Çizelge 2). Ürünlerin su tutma kapasitesi arttıkça yağ tutma kapasitesinde azalma belirlenmiştir. Yağ tutma kapasitesi en yüksek olarak belirlenen dondurulmuş ürünler, \%95.7 ile limonlu (Li6-H) ya da \%96.39 ile sitrik asitli (Lt6-H) çözeltide bekletilen ve sadece haşlama işlemi uygulananlardır. En düşük yağ tutma kapasitesi \%76.19 ile sirkeli çözeltide bekletilen ve sadece haşlama işlemi uygulanan üründür ve işlemsiz ürünün yağ tutma kapasitesi ile istatistiksel olarak fark bulunmamıştır ( $p>0.05)$. Çizelge 3'te gösterildiği gibi son kızartma işlemi $180 \pm 1^{\circ} \mathrm{C}^{\prime}$ de 5 , 7 ve 9 dakika uygulanan ürünlerde su tutma kapasitesi azaldıkça yağ tutma kapasitesi artmıştır.

Çizelge 2. Kullanıma hazır dondurulmuş gölevez ürünlerine uygulanan analiz sonuçları ${ }^{3}$ Tablo 2. Results of analysis for ready-to-use frozen taro products ${ }^{3}$

\begin{tabular}{cllll}
$\begin{array}{c}\text { Ürünler } \\
\text { Samples }^{2}\end{array}$ & $\begin{array}{l}\text { Nem Oranı (\%) } \\
\text { Moisture } \\
\text { Content (\%) }\end{array}$ & $\begin{array}{l}\text { Kül Oranı (\%) } \\
\text { Ash Content (\%) }\end{array}$ & $\begin{array}{l}\text { Su Tutma Kapasitesi (\%) } \\
\text { Water Retention } \\
\text { Capacity (\%) }\end{array}$ & $\begin{array}{l}\text { Yağ Tutma Kapasitesi (\%) } \\
\text { Oil Holding Capacity (\%) }\end{array}$ \\
\hline İşlemsiz Ürün (Control) $^{1}$ & $78.59 \pm 0.27^{\mathrm{b}}$ & $8.09 \pm 0.27^{\mathrm{c}}$ & $212.83 \pm 5.69^{\mathrm{b}}$ & $80.59 \pm 3.96^{\mathrm{d}}$ \\
S6-H & $79.48 \pm 0.97^{\mathrm{b}}$ & $6.97 \pm 0.97^{\mathrm{bc}}$ & $182.21 \pm 11.78^{\mathrm{a}}$ & $76.19 \pm 4.19^{\mathrm{cd}}$ \\
S6-K & $66.42 \pm 0.63^{\mathrm{a}}$ & $5.86 \pm 0.63^{\mathrm{ab}}$ & $246.96 \pm 15.13^{\mathrm{c}}$ & $35.10 \pm 3.56^{\mathrm{a}}$ \\
Li6-H & $76.60 \pm 0.47^{\mathrm{b}}$ & $5.81 \pm 0.47^{\mathrm{ab}}$ & $230.79 \pm 5.27^{\mathrm{c}}$ & $95.70 \pm 3.31^{\mathrm{e}}$ \\
Li6-K & $68.55 \pm 0.68^{\mathrm{a}}$ & $4.94 \pm 0.68^{\mathrm{a}}$ & $273.63 \pm 13.32^{\mathrm{d}}$ & $64.67 \pm 2.57^{\mathrm{b}}$ \\
Lt6-H & $79.46 \pm 1.18^{\mathrm{b}}$ & $6.98 \pm 1.18^{\mathrm{bc}}$ & $206.14 \pm 8.56^{\mathrm{b}}$ & $96.39 \pm 1.98^{\mathrm{e}}$ \\
Lt6-K & $64.65 \pm 0.43^{\mathrm{a}}$ & $4.57 \pm 0.43^{\mathrm{a}}$ & $259.00 \pm 3.77^{\mathrm{cd}}$ & $70.70 \pm 3.14^{\mathrm{c}}$ \\
\hline
\end{tabular}

${ }^{1}$ Hiçbir işlem uygulanmamış, kontrol

${ }^{2}$ S:Sirkeli çözelti; Li:Limonlu çözelti; Lt:Sitrik asitli çözelti; H: Haşlama (Sadece haşlama işlemi uygulandığını); K: Ön kızartma (haşlama işlemi sonrasında ön kızartma işlemi uygulandığını); rakam haşlama süresini göstermektedir.

${ }^{3}$ Aynı sütun içerisinde belirtilen ortalama standart sapma değerlerinde kullanılan farklı harfler istatistiksel olarak farklıdır $(\mathrm{p}<0.05)$.

${ }^{1}$ Sample with no treatment, control

${ }^{2}$ S: Vinegar solution; Li: Lemon solution; Lt: Citric acid solution; H: Blanching (application of only blanching); K: Par-frying (application of frying after blanching treatment); number indicates blanching time.

${ }^{3}$ Values, indicated with mean \pm standard deviation, in the same column followed by different letters significantly different $(p<0.05)$. 
Çizelge 3. Son kızartma işlemi uygulanan kullanıma hazır dondurulmuş gölevez ürünlerinin analiz sonuçlar ${ }^{3}$ Table 3. Results of analysis for ready-to-use frozen taro products after finish frying process ${ }^{3}$

\begin{tabular}{|c|c|c|c|c|c|}
\hline $\begin{array}{l}\text { Kızartma Süresi } \\
\text { (dk) } \\
\text { Deep-fat Frying } \\
\text { Time (min) }\end{array}$ & $\begin{array}{l}\text { Ürünler }^{2} \\
\text { Samples }^{2}\end{array}$ & $\begin{array}{l}\text { Nem Oranı (\%) } \\
\text { Moisture } \\
\text { content (\%) }\end{array}$ & $\begin{array}{l}\text { Kül Oranı (\%) } \\
\text { Ash content (\%) }\end{array}$ & $\begin{array}{l}\text { Su Tutma } \\
\text { Kapasitesi (\%) } \\
\text { Water Retention } \\
\text { Capacity (\%) }\end{array}$ & $\begin{array}{l}\text { Yağ Tutma } \\
\text { Kapasitesi (\%) } \\
\text { Oil Holding } \\
\text { Capacity (\%) }\end{array}$ \\
\hline \multirow{7}{*}{5} & İşlemsiz Ürün (Control) ${ }^{1}$ & $43.69 \pm 2.58^{c}$ & $6.05 \pm 0.04^{\mathrm{e}}$ & $283.17 \pm 2.02^{c}$ & $47.69 \pm 2.76^{\mathrm{bc}}$ \\
\hline & S6-H & $53.60 \pm 3.51^{d}$ & $3.25 \pm 0.23^{a}$ & $274.99 \pm 2.04^{c}$ & $36.03 \pm 2.35^{\mathrm{a}}$ \\
\hline & S6-K & $43.58 \pm 2.14^{c}$ & $4.70 \pm 0.50^{c}$ & $143.46 \pm 6.10^{\mathrm{a}}$ & $49.51 \pm 2.64^{c}$ \\
\hline & Li6-H & $52.64 \pm 1.83^{d}$ & $3.95 \pm 0.49^{b}$ & $293.38 \pm 5.56^{d}$ & $44.62 \pm 3.64^{\mathrm{b}}$ \\
\hline & Li6-K & $38.19 \pm 1.57^{b}$ & $5.29 \pm 0.52^{d}$ & $200.16 \pm 4.31^{\mathrm{b}}$ & $65.57 \pm 1.82^{d}$ \\
\hline & Lt6-H & $43.01 \pm 1.60^{c}$ & $5.10 \pm 0.26^{\mathrm{cd}}$ & $295.68 \pm 7.94^{d}$ & $64.07 \pm 1.82^{d}$ \\
\hline & Lt6-K & $33.55 \pm 2.91^{\mathrm{a}}$ & $3.80 \pm 0.64^{b}$ & $204.28 \pm 1.85^{\mathrm{b}}$ & $80.93 \pm 1.36^{\mathrm{e}}$ \\
\hline \multirow{7}{*}{7} & İşlemsiz Ürün (Control) & $31.45 \pm 3.10^{b}$ & $5.48 \pm 0.03^{\mathrm{e}}$ & $286.52 \pm 0.82^{\mathrm{e}}$ & $57.04 \pm 2.38^{c}$ \\
\hline & S6-H & $42.88 \pm 0.60^{e}$ & $3.98 \pm 0.24^{c}$ & $289.34 \pm 4.21^{\mathrm{e}}$ & $40.84 \pm 3.47^{a}$ \\
\hline & S6-K & $34.17 \pm 0.66^{c}$ & $3.28 \pm 0.17^{\mathrm{a}}$ & $156.78 \pm 3.97^{a}$ & $47.93 \pm 2.80^{\mathrm{b}}$ \\
\hline & Li6-H & $38.52 \pm 1.15^{d}$ & $3.47 \pm 0.24^{\mathrm{ab}}$ & $287.78 \pm 5.02^{\mathrm{e}}$ & $48.59 \pm 4.83^{b}$ \\
\hline & Li6-K & $32.92 \pm 0.70^{b c}$ & $4.74 \pm 0.02^{d}$ & $224.83 \pm 3.19^{c}$ & $63.20 \pm 1.69^{c}$ \\
\hline & Lt6-H & $26.86 \pm 1.27^{\mathrm{a}}$ & $3.55 \pm 0.22^{\mathrm{ab}}$ & $266.35 \pm 7.51^{d}$ & $75.55 \pm 1.90^{d}$ \\
\hline & Lt6-K & $27.60 \pm 0.11^{a}$ & $3.59 \pm 0.41^{\mathrm{b}}$ & $207.45 \pm 3.72^{\mathrm{b}}$ & $75.91 \pm 5.65^{d}$ \\
\hline \multirow{7}{*}{9} & İşlemsiz Ürün (Control) & $26.47 \pm 0.21^{c}$ & $4.34 \pm 0.35^{c}$ & $290.55 \pm 1.28^{d}$ & $61.38 \pm 1.59^{c}$ \\
\hline & S6-H & $39.56 \pm 1.16^{d}$ & $5.18 \pm 0.47^{d}$ & $296.36 \pm 4.02^{\mathrm{e}}$ & $43.89 \pm 4.26^{a}$ \\
\hline & S6-K & $27.52 \pm 0.32^{c}$ & $3.48 \pm 0.23^{b}$ & $189.74 \pm 7.02^{\mathrm{a}}$ & $45.42 \pm 2.04^{\mathrm{a}}$ \\
\hline & $\mathrm{Li6}-\mathrm{H}$ & $27.70 \pm 0.91^{c}$ & $3.13 \pm 0.18^{a b}$ & $285.93 \pm 3.41^{d}$ & $48.02 \pm 1.78^{\mathrm{ab}}$ \\
\hline & Li6-K & $24.52 \pm 0.24^{b}$ & $4.15 \pm 0.42^{c}$ & $240.83 \pm 4.08^{c}$ & $51.41 \pm 2.73^{b}$ \\
\hline & Lt6-H & $21.25 \pm 0.70^{\mathrm{a}}$ & $3.02 \pm 0.01^{a}$ & $220.07 \pm 5.92^{b}$ & $65.88 \pm 2.42^{d}$ \\
\hline & Lt6-K & $21.10 \pm 3.27^{a}$ & $3.16 \pm 0.11^{\mathrm{ab}}$ & $220.57 \pm 3.95^{b}$ & $83.42 \pm 2.47^{c}$ \\
\hline
\end{tabular}

${ }^{1}$ Hiçbir işlem uygulanmamış, kontrol

${ }^{2}$ S: Sirkeli çözelti; Li: Limonlu çözelti; Lt: Sitrik asitli çözelti; H: Haşlama (Sadece haşlama işlemi uygulandığını); K: Ön kızartma (haşlama işlemi sonrasında ön kızartma işlemi uygulandığını); rakam haşlama süresini göstermektedir.

${ }^{3}$ Aynı sütun ve aynı son kızartma süreleri satırı içerisinde belirtilen ortalama sstandart sapma değerlerinde kullanılan farklı harfler istatistiksel olarak farklıdır $(\mathrm{p}<0.05)$.

${ }^{1}$ Sample with no treatment, control

${ }^{2} S$ : Vinegar solution; Li: Lemon solution; Lt: Citric acid solution; H: Blanching (application of only blanching); K: Par-frying (application of frying after blanching treatment); number indicates blanching time.

${ }^{3}$ Values, indicated with mean \pm standard deviation, in the same column followed by different letters significantly different $(p<0.05)$.

Gıdalarda renk, kaliteyi ve albenisini belirleyen önemli bir faktördür. CIE renk sisteminde $L^{*}$ (açıklık-koyuluk), a* (kırmızılık-yeşillik) ve $b^{*}$ (sarılık-mavilik) değerleri ile ürünlerin renk özellikleri ifade edilir (Gamlı, 2015). Çizelge 4'te gösterilen kullanıma hazır dondurulmuş gölevez ürünlerinin $L^{*}$ renk değerleri incelendiğinde sadece haşlama işlemi uygulanmış ürünler (S6-H; Li6-H; Lt6-H) ile işlemsiz ürünün en açık renge sahip olduğu ve aralarında istatistiksel olarak fark olmadığı belirlenmiştir ( $p>0.05)$. Ön kızartma işlemi uygulanan ürünlerde (S6-K; Li6-K; Lt6-K), Maillard reaksiyonunun etkisi (Fennema, 1996) ile $L^{*}$ değerinde azalma, dolayısıyla renkte koyulaşma gözlemlenmiştir. Patates ile gölevez ürünlerinin renk değerleri karşılaştırıldığında, patates renginin gölevez ürünlerinden koyu olduğu belirlenmiştir $(p<0.05)$. Benzer şekilde patatesin $a^{*}, b^{*}$ ve $\Delta E^{*}$ değerleri gölevez ürünlerinden istatistiksel olarak farklılık göstermiş, patateste gölevez ürünlerine göre daha sarımsı ve yüksek toplam renk farkı belirlenmiştir. Son kızartma işlemi $180 \pm 1^{\circ} \mathrm{C}^{\prime}$ de 5,7 ve 9 dakika uygulanan gölevez ürünlerinde genel olarak ön kızartma işlemi uygulandığı zaman L* değerinde artış dolayısıyla renkte koyulaşma, a* ve $b^{*}$ değerlerinde düşme böylece sarımsı renkte azalma gözlemlenmiştir (Çizelge 5). Yapılan bir çalışmada, dondurulmuş Okinawa türü tatlı patates üretimi için uygulanan ön kızartma işleminin renkte koyulaşmaya sebep olduğu belirlenmiştir (Oner ve Wall, 2012). 
Çizelge 4. Kullanıma hazır dondurulmuş gölevez ürünleri renk değerleri ${ }^{3}$

Table 4. Color values of ready-to-use frozen taro products ${ }^{3}$

\begin{tabular}{|c|c|c|c|c|}
\hline $\begin{array}{l}\text { Ürün Kodu }{ }^{2} \\
\text { Product Code }\end{array}$ & $L^{*}$ & a* & $b^{*}$ & $\Delta \mathrm{E}^{*}$ \\
\hline Patates (Potato) & $63.00 \pm 1.23^{a}$ & $-4.98 \pm 0.37^{a}$ & $20.33 \pm 1.83^{d}$ & $34,88 \pm 2.41^{\mathrm{e}}$ \\
\hline İşlemsiz Ürün (Control) ${ }^{1}$ & $80.74 \pm 2.52^{\text {de }}$ & $-2.71 \pm 0.55^{b c}$ & $10.08 \pm 0.59^{c}$ & $14.31 \pm 2.13^{\mathrm{ab}}$ \\
\hline S6-H & $81.96 \pm 3.42^{\mathrm{e}}$ & $-2.86 \pm 0.33^{b}$ & $9.33 \pm 0.59^{b c}$ & $12.96 \pm 2.98^{\mathrm{a}}$ \\
\hline S6-K & $74.27 \pm 0.51^{c}$ & $-2.66 \pm 0.08^{b c}$ & $8.26 \pm 0.04^{\mathrm{abc}}$ & $19.86 \pm 0.50^{c}$ \\
\hline Li6-H & $79.18 \pm 0.29^{d}$ & $-2.66 \pm 0.16^{b c}$ & $8.25 \pm 0.28^{\mathrm{abc}}$ & $15.12 \pm 0.32^{b}$ \\
\hline Li6-K & $71.91 \pm 1.15^{b}$ & $-2.90 \pm 0.20^{b}$ & $7.38 \pm 1.03^{\mathrm{ab}}$ & $22.08 \pm 0.96^{d}$ \\
\hline Lt6-H & $80.94 \pm 0.51^{\text {de }}$ & $-2.21 \pm 0.01^{d}$ & $6.95 \pm 2.24^{\mathrm{a}}$ & $13.41 \pm 0.56^{\mathrm{ab}}$ \\
\hline Lt6-K & $73.91 \pm 0.26^{c}$ & $-2.42 \pm 0.03^{\mathrm{cd}}$ & $7.55 \pm 1.52^{\mathrm{ab}}$ & $20.12 \pm 0.00^{c}$ \\
\hline
\end{tabular}

${ }^{1}$ Hiçbir işlem uygulanmamış, kontrol

${ }^{2}$ S: Sirkeli çözelti; Li: Limonlu çözelti; Lt: Sitrik asitli çözelti; H: Haşlama (Sadece haşlama işlemi uygulandığını); K: Ön kızartma (haşlama işlemi sonrasında ön kızartma işlemi uygulandığını); rakam haşlama süresini göstermektedir.

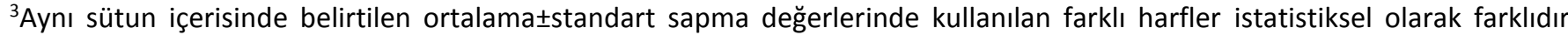
$(\mathrm{p}<0.05)$.

${ }^{1}$ Sample with no treatment, control

${ }^{2} S$ : Vinegar solution; Li: Lemon solution; Lt: Citric acid solution; H: Blanching (application of only blanching); K: Par-frying (application of frying after blanching treatment); number indicates blanching time.

${ }^{3}$ Values, indicated with mean \pm standard deviation, in the same column followed by different letters significantly different $(p<0.05)$.

Çizelge 5. Son kızartma işlemi uygulanan kullanıma hazır dondurulmuş gölevez ürünlerinin renk analizi sonuçları ${ }^{3}$ Table 5. Color values of ready-to-use frozen taro products after finish frying ${ }^{3}$

\begin{tabular}{|c|c|c|c|c|c|}
\hline $\begin{array}{l}\text { Kızartma } \\
\text { Süresi (dk) } \\
\text { Finish Frying } \\
\text { Time (min) }\end{array}$ & $\begin{array}{c}\text { Ürün Kodu }{ }^{2} \\
\text { Sample Code }\end{array}$ & $L^{*}$ & $a^{*}$ & $b^{*}$ & $\Delta \mathrm{E}^{*}$ \\
\hline \multirow{8}{*}{ (1) } & Patates (Potato) & $65.02 \pm 1.52^{\mathrm{bc}}$ & $-2.13 \pm 0.66^{a}$ & $24.97 \pm 1.63^{\mathrm{cd}}$ & $35.32 \pm 0.34^{\text {cde }}$ \\
\hline & İşlemsiz Ürün (Control) ${ }^{1}$ & $61.02 \pm 1.37^{a}$ & $1.28 \pm 0.68^{d}$ & $22.51 \pm 2.36^{\mathrm{a}}$ & $37.38 \pm 0.04^{\mathrm{e}}$ \\
\hline & S6-H & $69.48 \pm 2.87^{d}$ & $0.16 \pm 0.78^{\mathrm{bcd}}$ & $23.48 \pm 0.29^{a b c}$ & $30.81 \pm 2.44^{a}$ \\
\hline & S6-K & $66.42 \pm 2.28^{c}$ & $-0.67 \pm 0.33^{b}$ & $22.02 \pm 0.26^{\mathrm{a}}$ & $32.41 \pm 2.05^{\mathrm{ab}}$ \\
\hline & Li6-H & $64.12 \pm 1.37^{\mathrm{b}}$ & $3.61 \pm 0.18^{e}$ & $25.55 \pm 1.79^{d}$ & $36.55 \pm 0.09^{\text {de }}$ \\
\hline & Li6-K & $62.01 \pm 0.96^{a}$ & $0.02 \pm 0.55^{b c}$ & $22.68 \pm 0.50^{\mathrm{ab}}$ & $36.52 \pm 0.59^{\text {de }}$ \\
\hline & Lt6-H & $65.78 \pm 0.83^{b c}$ & $2.91 \pm 0.43^{\mathrm{e}}$ & $24.95 \pm 0.46^{\mathrm{cd}}$ & $34.76 \pm 0.44^{\mathrm{cd}}$ \\
\hline & Lt6-K & $65.79 \pm 0.02^{b c}$ & $0.67 \pm 1.25^{\mathrm{cd}}$ & $24.37 \pm 1.01^{\mathrm{bcd}}$ & $34.30 \pm 0.66^{b c}$ \\
\hline \multirow{8}{*}{7} & Patates (Potato) & $62.90 \pm 1.80^{\mathrm{bc}}$ & $1.14 \pm 0.83^{\mathrm{a}}$ & $27.57 \pm 0.50^{d}$ & $38.54 \pm 1.18^{\text {cde }}$ \\
\hline & İşlemsiz Ürün (Control) & $61.00 \pm 2.15^{b}$ & $4.68 \pm 0.22^{d}$ & $27.04 \pm 1.45^{d}$ & $40.09 \pm 0.88^{\mathrm{de}}$ \\
\hline & S6-H & $63.25 \pm 2.84^{\mathrm{bc}}$ & $3.51 \pm 1.10^{c}$ & $26.42 \pm 0.39^{c d}$ & $37.66 \pm 2.63^{b c}$ \\
\hline & S6-K & $66.22 \pm 0.04^{d}$ & $1.65 \pm 0.18^{\mathrm{ab}}$ & $27.24 \pm 1.17^{d}$ & $35.73 \pm 0.78^{b}$ \\
\hline & Li6-H & $64.23 \pm 0.15^{\mathrm{cd}}$ & $0.90 \pm 0.02^{\mathrm{a}}$ & $19.94 \pm 1.53^{\mathrm{a}}$ & $33.30 \pm 0.87^{a}$ \\
\hline & Li6-K & $58.52 \pm 0.24^{\mathrm{a}}$ & $2.04 \pm 0.19^{\mathrm{ab}}$ & $24.05 \pm 0.76^{b}$ & $40.32 \pm 0.13^{e}$ \\
\hline & Lt6-H & $63.55 \pm 1.33^{b c}$ & $3.47 \pm 0.07^{c}$ & $26.90 \pm 0.44^{d}$ & $37.77 \pm 0.81^{b c c}$ \\
\hline & Lt6-K & $61.98 \pm 2.14^{\mathrm{bc}}$ & $2.36 \pm 1.78^{\mathrm{bc}}$ & $24.97 \pm 1.71^{\mathrm{bc}}$ & $37.84 \pm 2.84^{\mathrm{bcc}}$ \\
\hline \multirow{8}{*}{9} & Patates (Potato) & $57.31 \pm 1.30^{\mathrm{ab}}$ & $1.62 \pm 0.58^{\mathrm{a}}$ & $26.20 \pm 0.42^{\mathrm{bcd}}$ & $42.46 \pm 1.30^{\mathrm{b}}$ \\
\hline & İşlemsiz Ürün (Control) & $56.70 \pm 0.24^{a}$ & $7.58 \pm 2.00^{\mathrm{e}}$ & $27.33 \pm 1.52^{\mathrm{cd}}$ & $44.21 \pm 1.33^{b}$ \\
\hline & S6-H & $60.72 \pm 2.33^{\mathrm{bcd}}$ & $3.92 \pm 1.81^{\mathrm{bcd}}$ & $24.33 \pm 1.93^{\mathrm{ab}}$ & $38.77 \pm 3.26^{a}$ \\
\hline & S6-K & $61.18 \pm 2.50^{\mathrm{cd}}$ & $2.35 \pm 0.21^{\mathrm{ab}}$ & $25.98 \pm 1.36^{\mathrm{abcd}}$ & $39.12 \pm 1.31^{\mathrm{a}}$ \\
\hline & Li6-H & $58.29 \pm 1.76^{\mathrm{abc}}$ & $5.25 \pm 0.85^{d}$ & $25.45 \pm 0.14^{\mathrm{abc}}$ & $41.55 \pm 1.72^{\mathrm{ab}}$ \\
\hline & Li6-K & $58.94 \pm 5.76^{a b c}$ & $3.04 \pm 0.92^{\mathrm{abc}}$ & $26.39 \pm 1.81^{\mathrm{cd}}$ & $41.34 \pm 3.94^{\mathrm{ab}}$ \\
\hline & Lt6-H & $62.94 \pm 2.60^{d}$ & $3.79 \pm 0.43^{b c d}$ & $27.64 \pm 0.84^{d}$ & $38.74 \pm 1.59 a$ \\
\hline & Lt6-K & $55.79 \pm 1.58^{a}$ & $4.31 \pm 0.55^{\mathrm{cd}}$ & $24.12 \pm 0.54^{a}$ & $42.94 \pm 1.20^{\mathrm{b}}$ \\
\hline
\end{tabular}

${ }^{1}$ Hiçbir işlem uygulanmamış, kontrol

${ }^{2}$ S: Sirkeli çözelti; Li: Limonlu çözelti; Lt: Sitrik asitli çözelti; H: Haşlama (Sadece haşlama işlemi uygulandığını); K: Ön kızartma (haşlama işlemi sonrasında ön kızartma işlemi uygulandığını); rakam haşlama süresini göstermektedir.

${ }^{3}$ Aynı sütun ve aynı son kızartma süreleri satırı içerisinde belirtilen ortalama harfler istatistiksel olarak farklıdır $(p<0.05)$.

${ }^{1}$ Sample with no treatment, control

${ }^{2}$ S: Vinegar solution; Li: Lemon solution; Lt: Citric acid solution; H: Blanching (application of only blanching); K: Par-frying (application of frying after blanching treatment); number indicates blanching time.

${ }^{3}$ Values, indicated with mean \pm standard deviation, in the same column followed by different letters significantly different $(p<0.05)$. 


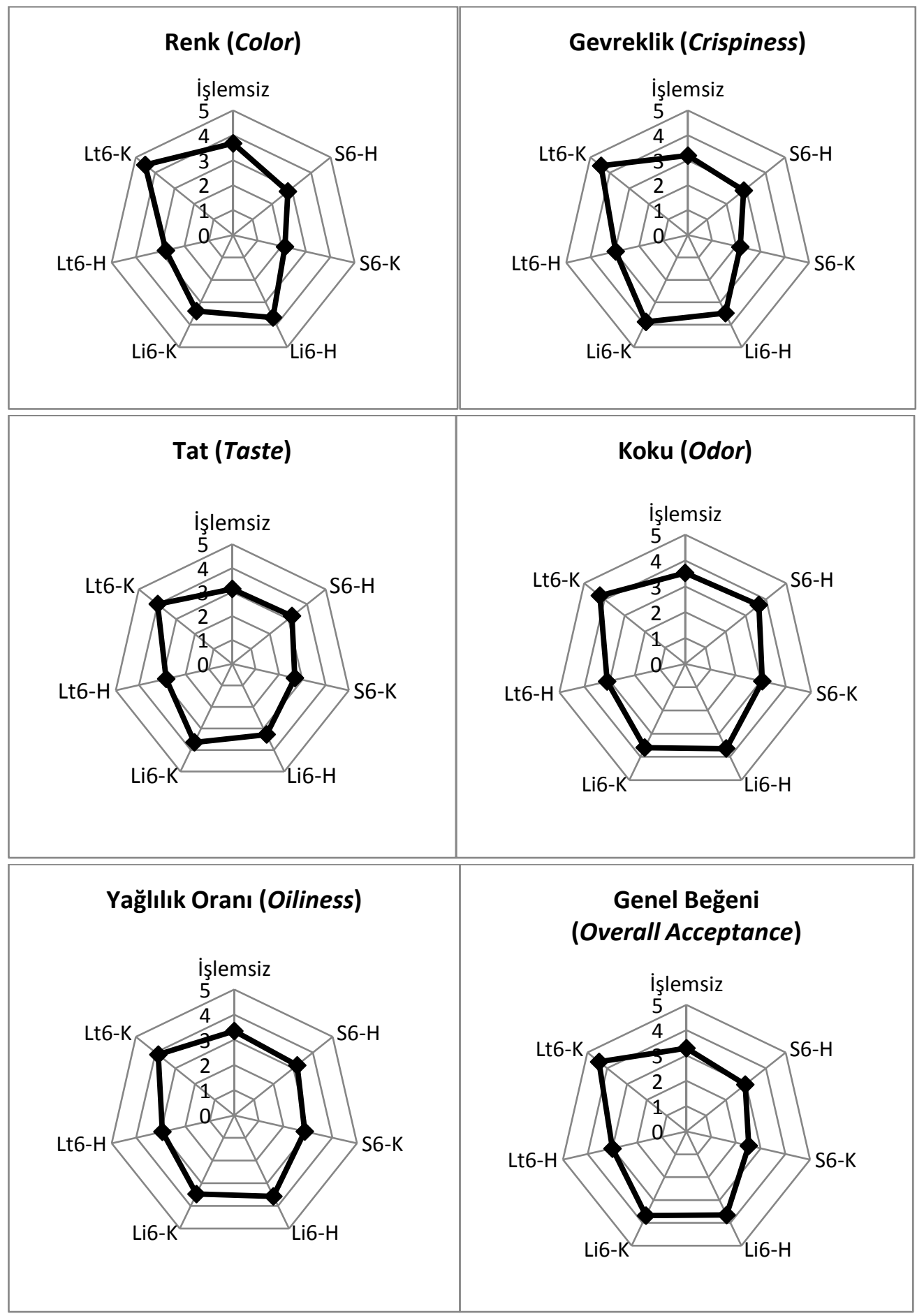

Şekil 1. Gölevez ürünlerine uygulanan duyusal analiz puanlama testi

Figure 1. Sensory evaluation hedonic scale rating test for taro products

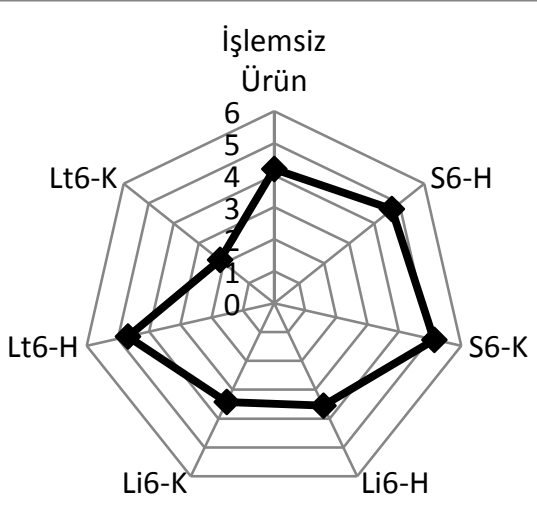

Şekil 2. Gölevez ürünlerine uygulanan duyusal analiz sıralama testi Figure 2. Sensory evaluation ranking test for taro products 
Duyusal analiz gıdaların farklı karakteristik özelliklerine karşı görme, işitme, tatma, dokunma ve koklama duyuları sonucunda oluşan tepkileri analiz eden ve yorumlayan bir disiplindir (Altuğ Onoğur ve Elmacı, 2015). Bu çalışmada gölevez ürünlerine uygulanan farklı çözeltilerde bekletme, haşlama, ön kızartma gibi işlemlerin tüketici algısına etkisinin belirlenmesi amacıyla puanlama ve sıralama testleri yapılmıştır. Son kızartma işlemi $180 \pm 1^{\circ} \mathrm{C}^{\prime}$ de 7 dakika uygulanan 6 farklı işlemden geçirilmiş (S6-H; S6-K; Li6-H; Li6-K; Lt6-H; Lt6-K) ve işlemsiz gölevez ürünü renk, gevreklik, sertlik, tat, koku ve yağlılık oranı yönünden değerlendirilmiştir. Şekil 1'de gösterildiği gibi genel beğeni verilerine göre haşlama işlemi sonrasında ön kızartma uygulanan ürünlerden sitrik asitli çözeltide bekletilen Lt6-K en çok beğenilen, sirkeli çözeltide bekletilen S6-K ise en az beğenilen ürün olmuştur. Yağ tutma kapasitesi en yüksek olan sitrik asitli çözeltide bekletilen ürünlerden Lt6-K, duyusal analiz sonuçlarına göre gevreklik ve yağlılık oranında en yüksek puanı almıştır. Yağ oranı yüksek olan kızartılmış patates türü ürünler tat yönünden en çok beğenilmektedir. Okinawa türü mor renkli kızartılmış tatlı patateslerde benzer sonuç elde edilmiştir (Oner ve Wall, 2012). Sıralama testine göre gölevez ürünleri en çok beğenilenden en az beğenilene Lt6-K, Li6-K, Li6-H, işlemsiz (kontrol), Lt6-H, S6-H, S6-K olarak sıralanmaktadır (Şekil 2). Genel olarak sitrik asitli ve limonlu çözeltide bekletilen ve ön kızartma uygulanan ürünler beğenilirken, sirkeli çözeltide bekletilen ürünler beğenilmemiştir.

\section{Sonuçlar}

Kullanıma hazır dondurulmuş gölevez ürünlerinde en yüksek nem oranı sirkeli çözeltide bekletilen ve sadece haşlama işlemi uygulanan S6$\mathrm{H}$ ürünündedir. Son kızartma işlemi sonrasında ürünlerin nem oranlarında azalma belirlenmiştir. Kızartılmış ürünlerdeki kül oranı \%3.02 ile \%6.05 arasında değişmektedir. Ayrıca ürünlerdeki su tutma kapasitesi azaldıkça yağ tutma kapasitesinin arttığı gözlemlenmiştir. Son kızartma süresine bağlı olarak ürünlerin $L^{*}$ değerinde azalma, $a^{*}$ ve $b^{*}$ değerlerinde artma böylece ürün renginde koyulaşmanın yanı sıra kırmızılık ve sarılık olduğu belirlenmiştir. Duyusal analiz sonuçlarına göre sitrik asitli çözeltide bekletilen ve haşlama işlemi sonrasında ön kızartma uygulanan Lt6-K ürünü genel olarak en çok tercih edilen ürün olmuştur.

\section{Ekler}

Bu makale Erman Baş’ın Gölevezden Yarı Mamül Ürün Geliştirme Üzerine Bir Araştırma başlıklı yüksek lisans tezinden üretilmiştir.

\section{Çıkar Çatışması Beyanı: Makale yazarları} aralarında herhangi bir çıkar çatışması olmadığını beyan ederler.

\section{Kaynaklar}

Açar, M. (2011). Kızartılmış patateslerde kızartma sayısııın ve süresinin kızartma yağı ve patatesteki yağ asidi kompozisyonu üzerine etkisi. Yüksek Lisans Tezi, Sakarya Üniversitesi, Fen Bilimleri Enstitüsü, Sakarya.

Ahromrit, A. \& Nema, P.K. (2010). Heat and mass transfer in deep-frying of pumpkin, sweet potato and taro. Journal of Food Science and Technology, 47(6), 632-637.

Akgül, C., Ünver Alçay, A. \& Can, N. (2017). Gölevezin beslenmede kullanımı ve sağlık üzerine etkisi. Aydın Gastronomy, 1(2), 51-56.

AOAC (Association of Official Analytical Chemists) (1997). International official methods of analysis. 16th Edition, Arlington, VA, USA.

AOAC (Association of Official Analytical Chemists) (2005). Ash of flour, official method 923.03. Gaithersburg, MD, USA.

Agbor-Egbe, T. \& Rickard, J.E. (1991). Studyon the factors affecting storage of edible aroids. Annals of Applied Biology, 119(1), 121-130.

Altuğ Onoğur, T. \& Elmacı, Y. (2015). Gıdalarda duyusal değerlendirme. Sidas Yayınları, İzmir.

Arnaud-Vinas, M.D.R. \& Klaus, L. (1999). Pasta products containing taro (colocasia esculenta I. schott) and chaya (cnidoscolus chavamansa I. mcvaugh). Journal of Food Processing Preservation, 23(1), 120.

Bahado-Singh, P.S., Wheatley, A.O., Ahmad, M.H., Morrison, E.Y. \& Asemota, H.N. (2006). Food processing methods influence the glycaemic indices of some commonly eaten West Indian carbohydrate-rich foods. British Journal of Nutrition, 96(3), 476-481.

Bilgiçli, N. (2009). Effect of buckwheat flour on chemical and functional properties of tarhana. Lebensmittel Wissenschaft and Technologie - Food Science and Technology, 42(2), 514-518. 
Demiray, E. \& Tülek, Y. (2010). Donmuş muhafaza sırasında meyve ve sebzelerde oluşan kalite değişimleri. Akademik Gıda, 8(2), 36-44.

Fennema, O.R. (1996). Food Chemistry. Marcel Dekker Inc., New York, NY, s.1067.

Foster-Powell, K., Holt, S.H.A. \& Brand-Miller, J.C. (2002). International table of glycemic index and glycemic load values: 2002. The American Journal of Clinical Nutrition, 76(1), 5-56.

Gamlı, Ö.F. (2015). Laboratuar teknikleri ve temel gıda analizleri. Dora Yayıncılık, Bursa.

Göhl, B. (1981). Tropical feeds: Feed information summaries and nutritive values. Food and Agriculture Organization Animal Productions and Health Series No.12.

Gündüz, O. \& Emir, M. (2014). Dondurulmuş gıda tüketimini etkileyen faktörlerin analizi: Samsun ili örneği. Harran Tarım ve Gıda Bilimleri Dergisi, 14(3), 15-24.

Hayta, M., Alpaslan, M. \& Baysar, A. (2002). Effect of drying methods on functional properties of tarhana: A wheat flour yoghurt mixture. Journal of Food Science, 67(2), 740-744.

ITO (İstanbul Ticaret Odası) (2003). Dondurulmuş gıda sektör raporu. İstanbul ticaret odası etüt ve araştırma şubesi. https://www.yumpu.com/tr/document/read/235 85121/dondurulmus-gda-sektor-raporu-2003-ito (Erişim tarihi; 19.06.2019).

Kaya, B. \& Demirel Zorba, N.N. (2018). Farklı su aktivitesine sahip çeşitli gıdalarda küf ve maya yükünün belirlenmesi için kullanılan DRBC Agar ve DG18 Agar besiyerlerinin etkinliğinin karşılaştırılması. Ordu Üniversitesi Bilim ve Teknoloji Dergisi, 8(2), 206-214.

Külekçi, M., Topaloğlu, A. \& Aksoy, A. (2006). Dondurulmuş gıda tüketimini etkileyen sosyoekonomik özelliklerin belirlenmesi; erzurum ili örneği. Atatürk Üniversitesi Ziraat Fakültesi, 37(1), 91-101.

Oner, M.E. \& Walker, P.N. (2011). Effect of processing and packaging conditions on quality of refrigerated potato strips. Journal of Food Science, 76(1), S35S40.

Oner, M.E. \& Wall, M.M. (2012). Processing conditions for producing french fries from purple-fleshed sweet potatoes. Transactions of the American Society of Agricultural and Biological Engineers, 55(6), 22852291.

Palaniswami, M.S. \& Peter, K.V. (2008). Tuber and root crops. Horticulture science series Vol. 09. New India Publishing Agency, New Delhi, India

Sarıkaya, N. \& Korkmaz, N. (2012). Kültürel farklılıkların dondurulmuş gıda tüketim kalıplarına etkisi: Polonya-Türkiye karşılaştırması. Tüketici ve Tüketim Araştırmaları 4(1), 47-79.

Sefa-Dedeh, S. \& Agyir-Sackey, K.E. (2004). Chemical composition and the effect of processing on oxalate content of cocoyam xanthosoma sagittifolium and colocasia esculenta cormels. Food Chemistry, 85(4), 479-487.

Simsek, S. \& El, S.N. (2015). In vitro starch digestibility, estimated glycemic index and antioxidant potential of taro (colocasia esculenta I. schott) corm. Food Chemistry, 168, 257-261.

Şen, M., Akgül, A. \& Özcan, M. (2001). Gölevez [colocasia esculenta (I.) schott] yumrusunun fiziksel ve kimyasal özellikleri ile kızartma ve püreye işlenmesi. Turkish Journal of Agriculture and Forestry 25, 427-432.

USDA (United States Department of Agriculture), (2017). Nutrient database for standard reference. https://ndb.nal.usda.gov/ndb/search/list (Erişim tarihi; 24.08.2017)

Uylaşer, V. \& Başoğlu, F. (2014). Temel gıda analizleri. 2.baskı, Dora Yayıncılık, Bursa.

Yemenicioğlu, A., Özkan, M. \& Cemeroğlu, B. (1999). Some characteristics of polyphenol oxidase and peroxidase from taro (colocasia antiquorum). Turkish Journal of Agriculture and Forestry, 23, 425-430. 